\title{
A határ szerepe felépüló szenvedélybetegek narratív identitásában
}

\section{Bevezetés}

A tanulmány fókuszában a „,különbség” konstrukciói, a konstruálódás szociokulturális mechanizmusai és a különbségtétel jellegzetes tematikái állnak. A szerző célja annak vizsgálata, hogy az intézményesült formában rehabilitálódó, ${ }^{1}$ talpra álló szenvedélybetegek által használt, részben zsargon kifejezés, a „,normi-függő”2 bipoláris reláció hogyan erősíti és tartja fenn az elkülönböződést. Vizsgáljuk továbbá azt a felépülési folyamat különleges, köztes állapotában, egy magyarországi rehabilitációs intézet védett terében élő szenvedélybetegekkel készített interjúk alapján, hogy az „elkülönböződés”3 retorikája hogyan épül be, interiorizálódik a rehabilitáció során tanult nyelvhasználatba. A betegségtudat általános magyarázó elvként, modellként való múködése a vizsgált közösségben olyan narratív mintát szolgáltat a tagjai számára, amelynek segítségével koherens, elfogadható rendszerbe integrálható a feltárt élettörténeti anyag, s amely által markáns jellemvonással különíti el magát a „függő” a „normitól”.

A drogkérdés társadalmi felépítéséről írt tanulmányában Kelemen (2001) annak hármas tudományos megközelítésével foglalkozik. A történeti, az empirikus és az etnográfiai megközelítések triangulálása kapcsán hangsúlyozza az etnográfiai kutatások számára annak kitûnő terepként való megjelenését. A szerző szerint a „naivitás szakértője" kutatása során zárójelbe teszi saját dichotomizáló kategóriáit, törekvése a körülötte lévők dichotomizáló és valóságot konstruáló tevékenységének megismerésére irányul.

A saját társadalomra irányuló antropológiai kutatás egyik tárgya a társadalomból való szimbolikus kizáráson alapuló, ezen keresztül megnyilvánuló kulturális másság. „Arról a kulturális másságról van szó, melyet elsősorban a társadalom uralkodó szimbolikus struktúrái határoznak meg, arról a kulturális másságról, amely számára csupán a társadalom marginális pozíciói adottak, mivel a másság eredendően marginalitásként artikulálódik.” (Niedermüller 1993: 65.) Az antropológiai kutatás „dramaturgiája” alapján írásunk tárgya a kultúra hordozójának a saját kul-

1 A szerző Magyarországon, a Mérföldkő Egyesület Kovácsszénáján múködő addiktológiai rehabilitációs intézményében végez résztvevő megfigyelést.

2 A tanulmány során tárgyalt jelenség egyfajta partikuláris, helyi „,indoktrináltság” következménye, így annak értelmezése kizárólag az adott kontextusban lehetséges.

3 Az „elkülönböződés” terminusát Willis (2000) alapján értelmezzük, aki a „,betagozódás” ellentéteként megnyilvánuló, sajátos folyamatként tekint arra. 
túrájáról vallott képe: szenvedélybetegek megkérdezése arról, hogyan értelmezik függőségüket. Törekvésünk, hogy egy rehabilitációs közösség tagjainak belső kategóriáival közelítsük meg a szenvedélybetegséget, s azt a jelentéstartalmat, mely e kategória és a „,normi-függő” reláció mentén artikulálódik bennük. A tanulmány az egyik - Niedermüller által megfogalmazott - kulturális másságot „reprezentáló”, inherens viselkedési egységre, a magukat függőként identifikálók csoportjára fókuszál, illetve az addikciók kezelésével foglalkozó terápiás otthonok szub- és terápiás kultúrájának bizonyos hatásait vizsgálja az ott élőkre.

\section{Az átmenet szimbolikus tere}

A Van Gennep alapján Turner (2002 [1969]) által kidolgozott átmenetek rendszerének és a szenvedélybetegségből való felépülés dinamikus modelljének (Brown, 1985) öszszefüggéseit vizsgálva több párhuzam adódik az értelmezésben. A preliminális rítusok, melyek az elkülönülést, szeparációt hangsúlyozzák, a detoxikáló, absztinenciát beigazító időszakkal vonhatók párhuzamba. Ebben az esetben nemcsak a társadalmi struktúra egy bizonyos pontjáról való leválás jön létre, hanem egy „,kulturális feltételrendszertől”, azaz állapottól való elszakadást azonosíthatunk. Az előző világtól való elszakadás az addiktológiai kontextusban az utolsó szerhasználatot követő heteket foglalja magában. A szerhasználatról absztinenciára váltás jelentős pszichológiai változásokkal jár. A kezelésnek ebben a fázisában a józan gondolkodás és beszédmód, a józan diskurzus internalizálása még nem hozzáférhetố az átmenet előszobájában lévő személy számára. A liminális rítusok - melyek a marginalitás helyzetében jönnek létre - legmarkánsabb attribútuma a bizonytalanság. A rehabilitációs jelenlétet értelmezve a korai felépülés időszaka hordozza a legnagyobb veszélyt a szerhasználó számára a relapszus (visszaesés) tekintetében. A posztliminális rítusok az ,új”-hoz való csatlakozást testesítik meg. A folyamatos felépülés időszakában a szubjektum ismét állandó állapotba kerül, tudatosul benne, hogy új helyre érkezett. White (2001) szerint a függőre váró munka - amelyrôl az átmeneti rítus metaforája ad ismereteket - tapasztalati térképpel ruházza fel a személyt, amely hangsúlyozza a szeparáció, a liminalitás és a reinkorporáció fázisát.

A következôkben az addiktológiai rehabilitáció terét és az ott zajló munkát a liminalitás rítusainak szimbolikus helyszíneként értelmezzük. A terápiás otthonokban olyan emberek ideiglenes életvilágát ${ }^{4}$ kísérhetjük nyomon, akik a társadalom (mint rendszer) által felkínált életvilág (mint a rendszerszerúséghez mégiscsak alkalmazkodóbb életvilág) lehetőségeit elutasították, majd az ideiglenes életvilágban - a rehabilitáció átmeneti terében - tanulási, mimetikus folyamatokon keresztül jutnak el az elutasított életvilág transzformációjáig, hogy aztán újra elfoglalják benne helyü-

4 Az „életvilág” terminust a tanulmányban elsősorban habermasi értelemben használjuk. Erről lásd bővebben: Mándi Nikoletta: Az életvilág értelmezési lehetőségei az addiktológiai rehabilitáció gyakorlatában, in: Szociális Szemle, 2010/1. 
ket, azzal az eséllyel, hogy a társadalom általuk újrakonstruált képét képessé váljanak elfogadni. A társadalom rendszerén belül alrendszerekként felkínált „elfogadott” életvilág-narratívák képezik a „rehabilitációs kínálat” tárgyát, a kínálaton kívül eső, a társadalom által ,elutasított” életvilág-narratívákkal szemben. A 12 lépés ${ }^{5}$ által konceptuálisan keretezett addiktológiai rehabilitációs intézmények egyik törekvése olvasatunkban: a rendszeren belüli kínálat elfogadása képességének megszerzése az „értéktelenség” narratívájának „betegség”-narratívává való átírásával.

A TC-k (therapeutic community) filozófiája négy alaptételre épül. Az elsô az addikcióra vonatkozó nézeteket foglalja magában. Eszerint a droghasználat az egész személyiségre vonatkozó helytelen múködés, tanult viselkedés, amely más, diagnosztizálható rendellenességgel jár együtt. A második szerint a függő́ személyiség olyan viselkedési,- kognitív,- pszichológiai,-- társas és morális tulajdonságokkal rendelkezik, amelyek alkalmatlanná teszik a tiszta, funkcionálisan jól alkalmazott életvitel folytatására, ám mindezek ellenére képes személyes deficitjei legyőzésére és a funkcionális értékrend elsajátítására. A harmadik tétel a gyógyulás folyamatáról szól, mely az életvitel és identitás változásában ölt testet, és amely túlnő az anyagról való leszokáson. Mindez olyan komplex tanulási folyamatot feltételez, amelyben a relapszus esélye állandóan jelen van, így a többszöri kísérlet a folyamat általános jellemzőjévé válik. A negyedik tétel a módszerekról szól, melynek kiemelt területei a társas tanulás, a közösség megtartó erejébe vetett hit és az önsegítés (Perfas, 2004).

\section{A narratívák ,átalakításának nemes múvészete": a betegségtudat}

Az elkülönböződés mechanizmusai - melyek vizsgálata képezi dolgozatunk tárgyát - elsősorban a betegségtudat koncepcióján keresztül jelennek meg a terápiások életében. Résztvevő megfigyeléseim és az általam készített strukturált, és narratív biográfiai interjúk egyik alapvető tapasztalata, hogy a szenvedélybetegek által elbeszélt narratív identitás, a narratív helyreállítási mechanizmusok, az ezek alapján kialakuló szövegek nagy része dichotómiákon alapul. Az identitás és alteritás kifejeződése kapcsán megfogalmazott narratívumok vizsgálata alapján a társadalomba való, a korábbinál konformabb jellegú betagozódás vágya és a „visszakerülés” megfogalmazott célja ellenére a szenvedélybetegek nem additív módon reprezentálják önmagukat. A „normikkal” való élményközösség és a „normikkal” való összetartozás nem válik hangsúlyossá, hanem egyfajta szubsztraktív viszonyulás jön létre, azaz az elkülönböződés és az idegenség retorikus jegyei válnak meghatározóvá narratívumaikban. A fent említett tapasztalatok egyik lehetséges olvasata, hogy az interiorizáció - mely egyértelmúen érvényesül a rehabilitáció gyakorlatában az újonnan megszerzett tudás szövegkorpuszba való beépülése által - erősítheti ugyan a másság

5 A „12 lépés” az AA (Alcoholics Anonymous) által megfogalmazott felépülési folyamat stációit foglalja magában. Az Anonim Alkoholisták önsegító szerveződései elfogadják a betegségbőll való felépülés lehetőségét, ám a teljes gyógyulás megvalósulását nem. 
(esetünkben: a józanság) hatásait, hiszen kívülről belülre transzportálja azokat, azonban a másik (a „normi”) mássága megmarad, éppen a hozzá való viszony relatív állandóságában. Ezt az állandóságot hivatott fenntartani a betegségtudat is. A szenvedélybetegek reintegrációja a „normik” társadalmába, a józan kultúrába való visszailleszkedés oly módon valósul meg a narráció szintjén, hogy a függőség irreverzibilitása (a kezelhetőség ellenére fennálló visszafordíthatatlanság), örök tulajdonságként, jellemvonásként artikulálódik én-elbeszéléseikben.

A résztvevő megfigyelésem terepéül választott intézményben elsősorban a „,betegségtudat-csoport” közvetíti mindezt a terápián résztvevők számára. Az információ átadása mint terápiás tényező az egészséggel, betegséggel, függőséggel, pszichodinamikával kapcsolatos információk megosztását jelenti. A BT (betegségtudatcsoport) célja, hogy a résztvevők tisztában legyenek pl. az idegrendszer múködésével, betegségük tüneteivel, annak különféle vonatkozásaival. Elmondásuk szerint ez az egyik olyan foglalkozás, amely erôs motivációs hatást gyakorol rájuk. A szenvedélybetegségeket értelmező modellek közül a betegség- modell az, amire a „12 lépéses” rehabilitációs otthonokban alkalmazott terápia elsődlegesen épül. Az AA betegségmodellje mellett a Minnesota modell adaptációja szerint is a betegségtudat előhívása és annak fenntartása a sikeres terápia egyik kulcsa. A modell az alkoholizmusra mint multifaktoriális betegségre tekint, fiziológiai, pszichológiai, szociális és spirituális összetevőkkel. Másik lényeges eleme a betegségbôl való felépülés lehetőségének elfogadása, ugyanakkor a teljes gyógyulás megvalósulásának kizárása. Sharma (1986) szerint - aki a pszichiátria és pszichológia kapcsán a nozológia kialakulásának történelmi hátterét tekinti át tanulmányában - a lelki bajok és érzelmi zavarok lényegében nyitott rendszernek tekinthetôk, azaz a betegség lefolyása előre meghatározhatatlan. Ha viszont betegségentitásként kezeljük óket, szükségszerúvé válik egy diagnózisrendszer kialakítása és a nozológia szükséges eszközként való elfogadása. Az általam vizsgált addiktológiai rehabilitációs otthon gyakorlatában a betegségtudat ismeretelméleti háttérként konceptualizálódik, a rendszert és a kezelési módot meghatározó identikus elemként rajzolódik ki, sôt egyfajta paradigmaként annak indoktrinálása történik. A függőség medikalizálásának, egyben gyógyszer nélküli kezelésének paradoxona valójában két ellentétes irányú paradigma együttes érvényesülését jelenti. Az önsegítő csoportok prototípusa, az AA Buda (1992: 84.) szerint „radikális biológiai betegségelméletet fogad el ideológiának, de ezt csak az absztinencia biztosítására használja, egyébként minden szabálya és gyakorlata a társas hálózat által megerôsített személyes autonómia erősítését célozza."

A betegségtudat csoport 8 tematikusan felépített alkalomból áll. Az első három a neurokémiai összefüggéseket mutatja meg a függőség szempontjából. Anatómia és biológia van benne nagy mennyiségben, merthogy elóbb megnézzük, hogy hogyan múködik tulajdonképpen az emberi test, szervezet sejtszinten, milyen neurotranszmitterek vagy idegi átvivőanyagok, hormonok befolyásolják akár a mi biológiai funkcióinkat, illetve akár a viselkedésünket. Ez az átütő része. ( $F, 42$ éves nó, függó segítő) 
Watzlawick, Weakland és Fisch (1990: 129-135.) mára klasszikussá vált könyvében az ,átalakítás nemes múvészetérool” írnak. Az ,átalakítás” a különféle helyzetek felfogásának érzelmi vagy konceptuális keretének megváltoztatása, melynek eredménye a helyzethez rendelt jelentés s annak következményeinek megváltozása. Változáskoncepciójuk központi kategóriája, az „osztály”, olyan szellemi termékként konstituálódik, amely más valóságszinten helyezkedik el, mint a tárgy maga. Egy tárgy adott osztály tagjaként való konceptualizálása esetén az eredeti osztályhovatartozást nevezzük a tárgy „,realitásának”. Amennyiben azonban érzékelhetővé válik az alternatív osztályhovatartozás, ez az átalakítási múvelet válhat a változás hatásos eszközévé. A szenvedélybetegek esetében a szerhasználatukra vonatkozó eredeti osztályhovatartozás „,megfogalmazása” egyhangú képet mutat. A szerhasználó életét elsősorban az imagináriusban való mozgás jellemezi, a szimbolikus formák iránti igény elenyésző, a függóség mint tárgy realitása nem aktualizálódik a mindennapok során. A segítők feladata az imagináriusból a szimbolikusba való átlépés lehetőségének megteremtése, az érzelem és értelem nyelvhasználatban való megvalósulásának elősegítése. Bourdieu (2009: 247.) szerint az átírás egyfajta „társadalmasítás”, a „kulturális önkény struktúráinak bevésése", a fiziológiai események szimbolikus eseményekké alakítása. A betegségtudat kialakítása révén a függôségből „halálos” betegség válik. A függőség társadalmasítása (annak betegséggé transzformálása) zajlik tehát a rehabilitáció terében, annak tudatosítása, hogy ez a betegség nem gyógyítható ugyan, ám tünetmentessé tehetô, kezelhető, „megszelídíthető”.

A függőség biológiai meghatározása, hogy ingerület-átvivő anyagcsere-zavar. Gyakorlatilag ez úgy néz ki a mi esetünkben, hogy nem vagyunk képesek megélni olyanfajta örömfokot szer nélkül, mint például a normi. ( $F, 42$ éves nö, függő/segítő)

A közösség előtt való ,egyéni” beszéd teremti meg a „közös” beszéd, a másikra való reflektálás lehetôségét, az új narratíva létrejöttét, s végül az önmagára reflektáló én megszületését.

A BT (betegségtudat-csoport) segít meghozni a döntést. Amikor bejönnek, akkor le akarnak állni, ez egyértelmú. Igen ám, csak utána kiderül számukra is, hogy változás és változtatás nélkül nincs tartós józanság. Na, az már ugye gondot okoz, és kiderül, hogy csupa olyan dolgon kéne változtatni, amin nem is akarok, tehát szándékomban sem állt soha, mert én ugye csak leállni jöttem. Nem is változás ez, hanem változtatás. A hozzáállásodban, mindenhez: önmagadhoz, emberekhez, világhoz. Ez hosszú és fájdalmas munka." (F, 42 éves nó, függó segítő) 


\section{A ,,normi-függợ” reláció}

A terápián résztvevők életútja a „megszakított jellegư” fejlődést prezentálja. A lakókkal készített interjúk szinte mindegyikében megfogalmazódott az „egyszerú program bonyolult embereknek" gondolata, mely szerint a fokozott érzékenység, a realitáshoz való kapcsolódás mássága az, amely megkülönbözteti őket a „normiktól". Az idézett szövegekben az eredendően (nem az abuzív életszakasz hatására megmutatkozó), adottságként megnyilvánuló személyiségkarakter bontakozik ki.

Mi tanultunk betegségtudatot, és ott megtanultuk, hogy mi így is születtünk, tehát hogy ez egy őssejt-hiány, egy hibás gén. Hibás gén van a szervezetünkben, ami által drogfüggő valaki, játékfüggő, van, aki gyógyszer, van, aki alkohol, de hogy egy gén benne van a szervezetünkben, ez egy hibás gén, őssejt-hiánynak hívjuk, és valószínú, hogy a családunkból hozott ez. Tehát nem pont anyuka, apuka, hanem akár régebbról visszanyúlva is. A normális ember örül egy autónak egy hétig. Egy függő ember örül egy autónak egy napig. A dopaminszintünk nem úgy termelődik, mint egy normális embernek. Például egy normális ember egy autónak örül egy hétig, és utána egy kicsit még mindig benne van, vagy visszatér a saját szintjére, normális szintre. Mi viszont örülünk egy napig, az nagyon jó, de utána viszont háromszor olyan rossz. (B, 21 éves nö, 121 napos, heroin)

Egzisztenciális szempontból Lukas (2009) szintén e két meghatározó motívumot azonosítja a függőség kérdése mentén. A nyomorúság és a szenvedés lenti helyzetében a fájdalom elnyomását, míg a bőség és unalom fenti állapotában az û́r kitöltését szolgálja a bódulat. Ami mindkét esetben közös, az a valóság (a közös Gond, az Egyenes világ) előli menekülés azáltal, hogy a szenvedélybeteg nem magát a létet, hanem a lét emocionális tükröződését fogadja el impulzusként.

(...) a nehéz sors nincs benne, az indulás, meg hogy kire mennyit mért a sors, anyagoztam együtt dúsgazdag gyerekekkel, meg akiket a szülei jól neveltek, meg végig ott voltak, el se váltak... (C, 31 éves férfi, 239 napos, heroin)

Nehezebben osztják meg magukat két dolog között, nekem könnyebb megosztanom a figyelmemet. Én tartok egy határt magamban. Ők elementárisabban, szenvedélyesebben vannak jelen pl. a munkában. Ha valami érdekli óket, akkor 100 százalékig annak élnek. Ha lanyhul az érdeklődés, akkor látható is, hogy azzal nem tudnak annyira mit kezdeni: a kezdeti felfokozott lendületet nem tudják sokáig fenntartani, azt az állandóságot. (G, 38 éves nó, „,normi” segító)

Az egyénnek a társadalmi életképesség eléréséhez a társadalom valóságához tartozó objektivációkon kell magát ,átdolgoznia”. Az egyén - saját sorsa alakításának aktív résztvevőjeként - soha nem tökéletesen reprodukálja a fent említett objektivációkat, 
pusztán azok szubjektív variációját nyújtja. A szabályozás során a dinamikát tekintve két ellentétes irányú mozgás zajlik: a szociális objektivációk individuális szintre emelése és az individuális folyamatok szociális nívójára történő átfogalmazása. Az utóbbi során a kulturális szabályozás által hangsúlyozott, privilegizált konformitás az egyén részérôl történő elutasítása esetén feszültség keletkezhet (Angelusz 1996).

(...) nincs más választás, mint visszailleszkedni a társadalomba. Nem a társadalomnak a tagadásáról van szó, hanem hogy az egész rendszer ellen lázadtunk, aztán később beláttuk, hogy nem feltétlenül a rendszer ellen, viszont a betegségünk természetéból adódóan nekünk sosem jó az, ami van. Vagy beintegrálódsz ebbe a társadalomba, vagy beledöglesz, szó szerint megdöglesz. Az egyetlen, ami a rehabra elvonszolja az embereket, az az életösztön. (...) A társadalom ugyanolyan szar, mint volt, vagy még szarabb, elmehetek használni a nagy lázadásomban, a nagy nyomoromban, meg önsajnálatomban, meg elfogadás hiányában magamat kezelni, és akkor megöl az anyag." (F, 42 éves nö, függó segítő)

Bourdieu (2009: 234.) szerint szintén az objektív struktúrák azok, amelyek meghatározzák egy társadalmi környezetnek, kollektív tájnak a fiziognómiáját. A struktúrák hatékonyságának legrejtettebb elveként azonosítja a valóság, illetve a valóságok iránti érzéket, azt a képességet, amellyel az objektíve lehetséges jövốt anticipálni tudjuk.

(...) egy norminak talán kevesebbet kell dolgoznia azon, hogy elégedett tudjon lenni az élettel, meg a dolgoknak az alakulásával. Az elégedettség, és azt gondolom, hogy a boldogság a kulcsszó, főleg, hogy mesterséges úton kell keresnem, a normi közelebb áll hozzá. (C, 31 éves férfi, 239 napos, heroin)

A betagozódás ellentéteként megnyilvánuló elkülönböződés sajátos folyamatát Willis (2000) írja le. Míg a betagozódás az informális közegnek a formális paradigmába történő progresszív beépülésével jár, addig az elkülönböződés olyan kollektív tanulási folyamat, amelynek során az én megtanulja kritikus szemmel elhatárolni magát és a neki rendelt jövőt az eleve adott formális definícióktól. A társadalomszervezet félig-meddig való elutasításával létrejöhet egyfajta kulturális penetráció, ám ez egyszerre jelképezi a szabadságot, a választást és a transzcendenciát, ugyanakkor a rendszerbe való beilleszkedést is.

Azért mi irigykedünk a normikra. Egyébként nincs olyan kontraszt, merthogy a normi is ugyanolyan ember, mint én. Csak óneki megvan az a kis génje. Viszont egy függőnek az IQ-ja 125, csak érzelmi intelligenciánk nincs... (D, 33 éves nó, 217 napos, alkohol, gyógyszer)

A pszichiátriai megbetegedések egyik oka a társadalmi létezés értelmének elvesztése. Az adaptációs zavarként értelmezett megbetegedésre Pethő (1986) a minden- 
napok kivételességeként tekint: a mindennapi életben keletkezik, az onnan való kényszerû kikerülésben folytatódik, a gyógyulás pedig újra a mindennapiság dimenziójának elfogadását feltételezi.

Ez nem igazán tanulható, kezelhető inkább. Itt ezt megtanulhatjuk, hogy hogy kell ezzel együtt élni. Amit itt megtanulunk, akár örömöt, örömöket, jó dolgoknak örülni, azt itt kicsiben megtanuljuk, az életben viszont nagyban megkapjuk. (B, 21 éves nó, 121 napos, heroin)

Vissza akarnak illeszkedni a normik társadalmába, de nekik mégis figyelembe kell venni azt, hogy ők nem tehetik ugyanazt, mint az átlagember. Viszszailleszkednek a társadalomba, elmennek egy munkahelyre, ahol utána mindenki elmegy lazítani egy sör mellett, de ôk ezt nem tudják megtenni, mert nekik nem egy pohár, hanem egy láda sör sem elég, aztán utána jön a választott szer a sör után. Ez egy paradoxon, de ebben az önsegítő mozgalomban több ilyen paradoxon is van. A BT igazából ennek tudatosításában segít nekik. ( $G, 38$ éves nö, „normi” segítő)

A strukturális alacsonyabbrendûség fogalmának (Turner 1997) értelmezése alapján a szenvedélybeteg gyakran, mint értékhordozó jelenik meg, misztikus hatalommal bír, a ,gyengék hatalmával”. Turner felfogása szerint a differenciálatlan egész modellje kerül szembe egy differenciált rendszerrel, melynek egységei státuszok és szerepek, s amelyben a társadalmi személy különböző pozíciókra hasad. A szenvedélybetegek képviselői a köztudatban elszakadtak a társadalmi kötöttségektől, státuszon, szerepen és pozíción túl léteznek, így a többségi társadalom képviselői számára irigylendő a konformitáshoz való csekély alkalmazkodás, a normatív szabályozás kötöttségeinek felrúgásával járó létforma.

(...) egy függő és egy normi mindenben különbözik, csak kinézetre nem. A normi valahogy tudja kezelni az életét. Most én nézek egy normit, énnekem egy külön faj, szóval egy külön faj, és ezt ne vedd sértésnek, te is normi vagy. Merthogy én sokszor beszélgetek normival, de hogy nem értik meg azt, amit beszélek, hogy én mit miért csinálok. (D, 33 éves nó, 217 napos, alkohol, gyógyszer)

Az említett megközelítések ugyanazt a problematikát helyezik előtérbe. A mindennapiság-kivételeződés, a lent-fent, az objektivációk-szubjektív variációk és a betagozódás-elkülönböződés dichotómiája a gondolkodásunkat átható bináris logika szemléletét jeleníti meg. A fenti ellentétpárok határain megjelenő lázadást a formalitás próbálja visszaszorítani, többek között betegségnek, devianciának bélyegzéssel. Ebben az értelemben a gyógyítás - mint a formalitás kiszolgálója - a „középpont felé igyekvés" törekvését hivatott elősegíteni. 


\section{Összefoglalás}

Írásunk törekvése a „normi-függő” statikus és bipoláris reláció mint oppozíciós modell érvényességének átgondolása és annak azonosítása, hogy miként tevődik át a rehabilitáció folyamatában manifesztálódó beszédmód a függó személy által használt metanyelvbe. A függőség kifejezéséhez, az arra vonatkozó magyarázatok megfogalmazásához magasabb logikai szint szükséges, mint amelyen a kifejezendő, megmagyarázandó van, ezért a terápiás modalitás metanyelv, jelentésre reflektáló beszédmód használatára ösztönöz. A magukat függóként identifikáló személyek megfigyeléseink alapján hasonló narratív identifikációs gyakorlat és az önmeghatározás hasonló mentális és szimbolikus stratégiái alapján hozzák létre az új narratív identitást. Az új, meghatározó narratíva domináns összetevője a betegségtudat, és a betegségtudat-csoportban tanult, interiorizálódott ismeretek összessége. A függő identitás valójában az alteritás hangsúlyozásában konstituálódik, ebben a betegségtudat kialakítása játssza a legfőbb szerepet, s ez nyelvileg olyan szövegekben valósul meg, mint a „normi-függő”” különbségtétel.

Olvasatunkban a normi és függô között húzódó határ intertextuális jellegénél fogva alkalmassá válik a narratívák találkozására, ám az oppozíciós modell nem veszti érvényét, sốt identifikációs kulcselemként hagyományozódik tovább, azaz a függó a normival szemben, ahhoz viszonyulva fogalmazza meg identikusnak vélt szimbolikus karakterisztikumait. A függőség magyarázatával kapcsolatosan eredendően adott egy narratív artikulációjú kifejezésmód, melyet a rehabilitáció terében tanult és interiorizált szóhasználat, a statikus, kategorikus nyelvi formulák (a pszichoterápia és a betegség-modell terminológiai készletéből kölcsönzött kifejezések, pl.: azonosulás, elhárító mechanizmusok, őssejt-hiány) használata némileg visszaszorít. Az átmenet terében nyelvi homogenitás, egyfajta nyelvi dogmarendszer rajzolódik ki, amelynek egyik meghatározó, kiváltó eleme a betegségtudat. A kezelési modalitásra jellemző dialógusjellegú, esemény- és folyamatleírásra törekvő dinamikus beszédmód (pl.: drogkarrier-elbeszélések) mellett a betegségtudatcsoport homogenizált nyelvezete is megjelenik. A fennálló és mesterségesen fenntartott dichotómiát („,normi-függő” reláció) ugyanakkor ebben a kontextusban a rehabilitációs térben megfogalmazódó identitás-narratívumok dialektikává formálják: a kezdeti textuális különnemúségek képesek áthatni, penetrálni egymás szövegeit, így a terápia későbbi szakaszára az elbeszélések „hasonnemúvé” válnak. Kollektív azonosságteremtô narratívumok, közösségi azonosság-konstrukciók jönnek létre. Az identitás és alteritás e tanulmányban tárgyalt kérdéskörének egyik legfontosabb mozzanata a szerző törekvése alapján, hogy az általunk vizsgált oppozíciós modell fennmaradása ellenére szintén szolgálhatja a „közös” észrevételét, csökkentheti a határ statikusságát és merevségét: a saját értékek, szimbólumok és nyelv kidolgozása ugyan különbséget fejez ki, ám elősegíti a társadalmi láthatóságot, s ez által megszólíthatóságot biztosít.

A függőség betegségként való értelmezése a rehabilitáció kezdeti szakaszához képest - amikor döntően az individuális konnotációk érvényesülnek - fokozatosan módosul: a szimbólumteremtô közösség konvencionális konnotációja válik uralko- 
dóvá. A betegségtudat kerettörténetté válása konstruktív irányba mutat, annak ellenére, hogy a „gén történet” homályos jelentéshalmazt jelöl. A klinikai koncepción túl tehát egyfajta kulturális toposz is létrejön a rehabilitáció terében, amely az adott esetekben a függő identitáshoz kapcsolt lehetséges interpretációként alternatív történeteket hoz létre.

\section{Hivatkozott irodalom}

ANGelusz ERzséBet (1996): Antropológia és nevelés. Budapest, Akadémiai.

Bourdieu, Pierre (2009): A gyakorlat elméletének vázlata. Három kabil etnológiai tanulmány. Budapest, Napvilág.

Brown, Stephanie (1985): Treating the Alcoholic: A Developmental Model of Recovery. New York, John Wiley and Sons.

BudA, BÉla (1992): Az alkohológia új távlatai. In Utak az alkoholproblémák megértéséhez megelözéséhez és korai kezelésbevételéhez. Válogatott tanulmányok. Budapest, Alkoholizmus Elleni Bizottság.

Chodorow, Nancy (2000): A feminizmus és a pszichoanalitikus elmélet. Budapest, Új Mandátum.

Fernando B. Perfas (2004): Therapeutic Community Social Systems Perspective, New York-Lincoln-Shanghai, iUniverse.

Kelemen, GÁbor (2001): A drogkérdés társadalmi felépítése és ennek hatása a szenvedélybetegek kezelésére (Módszertani megfontolások). In Szenvedélybetegség, család, pszichoterápia. Addiktológiai és pszichoterápiás tanulmányok. Pécs, Pro Pannonia.

LuKas, ElisabeTh (2005): Freiheit und Identität: Logotherapie bei Suchtproblemen. München-Wien, Profil.

NiEDERMÜLlER, PÉTER (1993): Empirikus kultúrakutatás avagy az antropológia esélyei Kelet-Európában. In A komplex kultúrakutatás dilemmái a mai Magyarországon. Miskolc, ME, Kulturális és Vizuális Antropológiai Tanszék.

Pethő, Bertalan (1986): Pszichiátria és társadalmi ügy. Budapest, Magvető.

SHARMA, SoHAn LAL (1986): A nozológia kialakulásának történelmi háttere a pszichiátriában és a pszichológiában. In Pethő Bertalan (szerk.): Pszichiátria és emberkép. Budapest, Gondolat, 382-394.

TURNER, Victor (2002 [1969]): A rituális folyamat. Budapest, Osiris.

Watzlawick, Paul-Weakland, John H. (1974): Change. New York-London, Norton.

White, Michael (2001): A fogyasztói kultúrának szóló kihívás. Átmeneti rítusok és elfogadó közösségek. In Az addiktológia horizontja. Pécs, PTE Egészségügyi Főiskolai Kar.

Willis, PAUl (2000): A skacok. Iskolai ellenkultúra, munkáskultúra. Budapest, Új Mandátum. 